\title{
O Código Penal e a pena de morte
}

\section{G. de Almeida Moura}

O Código Penal brasileiro de 1940 não incluiu, na relação do art. 28, a pena de morte.

Embora se possa afirmar, sem receio de contestação ponderavel, que foi melhor assim, perguntamos se, constitucionalmente, tinha o legislador essa liberdade.

$\mathrm{O}$ art. 122 n. 13 da Constituição de 1937 dispusera que, além dos casos previstos na legislação militar para o tempo de guerra, "poderia" a lei prescrever a pena de morte, não só para alguns casos de crimes políticos, que vinham enumerados, como para o de "homicídio cometido por motivo futil e extremos de perversidade".

Era uma norma facultativa, dirigida ao legislador ordinário. Eis porque o saudoso professor Alcấntara Machado assim se pronunciou, na exposição de motivos de seu já famoso projeto de Código :

"Não propomos o restabelecimento da pena de morte, que a República aboliu. Inutil seria reabrir um debate secular, em que se esgotaram, de parte a parte, todos os argumentos. Basta a convicção, que temos, de que as condições atuais do meio brasileiro não exigem a adoção de uma penalidade, contra a qual se levantam objeções da maior gravidade e transcendência.

Ressalvada a nossa maneira de encarar o problema, deixamos a solução ao critério do Governo; e, a exemplo de Jorge CoHL e EuSEBIo Gómez, autores do projeto argentino, redigimos as disposições correspondentes, para o caso do Governo entender de usar da faculdade conferida pelo art. 122 n. XIII da lei constitucional em vigor" ("Revista da Faculdade", XXXIV, II, maio-agosto de 1938, p. 215)

Acontece, no entanto, que, exatamente um dia após a motivação do eminente mestre, a lei constitucional n. 1 , de 16 de maio de 1938, que emendou o art. 122 n. 13 da Constituição, tornou obrigatório o preceito.

A emenda estabeleceu que a pena de morte "seria" aplicada nas hipóteses das letras $a$ a $j$.

A da letra $i$ se refere a atentados cometidos contra a vida, a incolumidade ou a liberdade do Presidente da República, e a da 
letra $j$ ao "homicídio cometido por motivo futil ou com extremos de perversidade"

Apesar-dos entendidos poderem discutir se o delito previsto na letra $i$ é de carater político, ou se é mixto, não ha dúvida que o da letra $j$ é de natureza comum, tanto que não iria o Código Penal juntá-lo às exceções do art. 360 .

É de se notar, ainda, que, no mesmo dia em que se promulgou a emenda constitucional, o decreto-lei n. 428, de 16 de maio de 1938, dispôs sobre o processo dos crimes definidos nas leis ns. 38 e 136, de 4 de abril e 14 de dezembro de 1935; repetiu, no art. $2 .^{\circ}$, ns. 1 a 8, a enumeração dos delitos políticos capitulados pela emenda constitucional; enfileirou, ao lado deles, no n. 9, os atentados contra a vida, a incolumidade ou a liberdade do presidente da República, e estabeleceú o processo de execução da pena: o fuzilamento, em uma das prisões do Estado, designada pelo ministro da Justiça e Negócios Interiores (art. 2. ${ }^{\circ}$, 3..$\left.^{\circ}\right)$

Ora, uma vez que a lei ordinária tratou, concomitantemente, de pôr em vigor, na parte política, o novo dispositivo constitucional, parece que, no que concerne ao delito comum nele previsto, não podia o codificador penal fugir ao cumprimento rigoroso do preceito maior, tanto que, se a emenda constitucional tivesse pretendido apenas acrescentar alguns casos aos que já vinham no texto primitivo, de 1937, não teria substituido a expressão “a lei poderá prescrever a pena de morte" por esta, de meridiana clareza: "a pena de morte será aplicada"

Quer dizer que, tendo sido pelo menos incompleto o Código Penal, ficamos diante da alternativa de reformá-lo, a ele e ao Código do Processo, ou de esperarmos que uma nova emenda constitucional restabeleça o texto primitivo da Constituição, pelo menos quanto ao crime comum. Somos pela segunda solução, desde que o sistema penológico do Código é satisfatório e atende, pelo seu pluralismo, moderação e flexibilidade, aos melhores requisitos da ciência moderna.

Insistimos no interessante aspecto da questão, por nos parecer que não basta a ampla faculdade legislativa, concedida ao Presidente da República pelo art. 180 da Constituição. Mesmo agora, no regime de exceção em que vivemos, existe o problema da inconstitucionalidade das leis, e o da imperatividade do texto fundamental. A Constituição continua a ocupar o ápice da hierarquia legal, e assim o tem entendido o próprio poder público, desde que, embora combinando o art. $174 \mathrm{com}$ o 180 da Constituição, não se descurou de publicar as chamadas leis constitucionais, sempre que achou de conveniência emendar dispositivos da Carta Nacional. 